\title{
Incidence of immediate postpartum hemorrhages in French maternity units: a prospective observational study (HERA study)
}

Françoise Vendittelli ${ }^{1,2,3^{*}}$, Chloé Barasinski ${ }^{1,2}$, Bruno Pereira ${ }^{4}$, Didier Lémery ${ }^{1,2,3}$ and the HERA Group

\begin{abstract}
Background: Most estimates of postpartum hemorrhage (PPH) are calculated from studies that use administrative or medical birth databases, and only a few from prospective observational studies.

Our principal objective was to estimate the incidence of PPH according to their severity (mild or severe) in vaginal deliveries (>500 mL, $\geq 1000 \mathrm{~mL}$ ) and cesareans (>1000 mL and $\geq 1500 \mathrm{~mL}$ ). The secondary objectives were to describe the incidence of PPH according to maternity unit characteristics, causes, and types of PPH management.

Methods: This prospective observational study took place in French maternity wards. Women who gave birth at a term $\geq 22$ weeks were eligible for the study. 182 maternity units participated in a study with prospective data collection from 1 February, 2011, to 31 July, 2011. The main outcome measure was PPH incidence.

Results: PPH incidence after vaginal delivery was $3.36 \%$ [95 \% Cl: 3.25-3.47 \%] and after cesareans $2.83 \%$ [95 \% Cl: 2.63-3.04\%]. The incidence of severe PPH after vaginal delivery was $1.11 \%$ [95 \% Cl: 1.05-1.18\%] and after cesareans $1.00 \%$ [95 \% Cl: 0.88-1.13\%]. This incidence rate varied according to maternity unit characteristics. The principal cause of PPH for both modes of delivery was uterine atony $(57.7 \%$ for vaginal births and $66.3 \%$ for cesareans). Vascular embolization was more frequent among women with cesareans (10.0 vs. $2.9 \%$ ), who also required transfusions more often (44.4 vs $12.7 \%$ ).

Conclusions: The incidence of PPH was lower than the rate expected from the literature. Effective treatment of uterine atony and optimizing the identification of blood loss remain important priorities.
\end{abstract}

Keywords: Blood transfusion, Cesarean, Maternal morbidity, Postpartum hemorrhage, Uterine atony

\section{Background}

Postpartum hemorrhage (PPH) remains a major cause of maternal deaths worldwide [1, 2]. In France, $\mathrm{PPH}$ was the leading cause of death, responsible for $18 \%$ of maternal deaths in the decade from 1998 to 2007 [3]. Hemorrhage-related events are among the most preventable causes of maternal death.

\footnotetext{
* Correspondence: fvendittelli@chu-clermontferrand.fr

'Pôle Femme et Enfant, Centre Hospitalier Universitaire de Clermont-Ferrand, Clermont-Ferrand 63003, France

2Université d'Auvergne, EA 4681, PEPRADE (Périnatalité, grossesse, Environnement, PRAtiques médicales et DEveloppement), Clermont Université, Clermont-Ferrand, France

Full list of author information is available at the end of the article
}

Previous studies have suggested that severe maternal morbidity may be a better indicator of the quality of obstetric care, particularly in developed countries where maternal mortality is rare [4-9]. Obstetric hemorrhage is the main cause of severe maternal morbidity $[6,7,10]$. There is, however, no universally accepted definition of $\mathrm{PPH}[11,12]$. Accordingly, definitions using various levels of estimated blood loss [7, 13-19], various quantities of transfused blood [7, 16], specific decreases in postpartum hemoglobin $[7,20]$, or composite criteria $[16,20-22]$ have all been used in previous publications.

The prevalence of PPH (defined as $\geq 500 \mathrm{~mL}$ blood loss) and severe PPH (defined as $\geq 1000 \mathrm{~mL}$ blood loss) are reported to be around 6.0 and $1.86 \%$ of all deliveries, 
respectively, and vary widely throughout the world [23]. Most estimates are calculated from observational studies that use administrative or medical birth databases [14, 17-19, 24-29]; only a few come from prospective observational studies $[15,20,30]$. Of the two French population-based studies [20,31], only one was prospective, conducted in 16 of the 33 maternity units of the Rhône-Alpes perinatal network in 2004-2005 [20]. The overall incidence of immediate PPH was $5.4 \pm 0.3 \%$, but the diagnosis was clinical in $82.5 \%$ of the severe cases and in $77.5 \%$ of milder ones; the remainder were detected by postpartum laboratory tests [20]. A broader incidence study therefore appeared useful, one that would include several French regions, be supported by French perinatal networks, and for which all participating professionals would apply a standard definition of PPH.

The principal objective of this study was to estimate the incidence of $\mathrm{PPH}$, as either relatively mild or severe, in vaginal $(>500 \mathrm{~mL}$ and $\geq 1000 \mathrm{~mL})$ and cesarean $(>1000 \mathrm{~mL}$ and $\geq 1500 \mathrm{~mL})$ deliveries. The secondary objectives were to describe the incidence of $\mathrm{PPH}$ according to characteristics of the maternity units, causes, and types of PPH management.

\section{Methods}

\section{Materials}

This prospective observational study was approved by a French institutional review board (Comité d'Ethique des Centres d'Investigation Clinique de l'Inter-région Rhônes-Alpes-Auvergne, Grenoble: CECIC): IRB 0917 on 9 November 2009]. Our study adhered to STROBE guidelines. All patients were informed about the study and that neither participation in it nor refusal to consent would affect their treatment, which would be the usual standard of care.

Eligible women had singleton or multiple pregnancies, regardless of parity, delivered stillborn or live born babies in a participating maternity unit by vaginal or cesarean delivery, at or after a gestation of 22 weeks (or, in the absence of a specific date for the beginning of the pregnancy, birth of a child $\geq 500 \mathrm{~g}$ ).

\section{Data source}

We contacted 43 French perinatal networks to request their support for this study of their maternity units. Twenty perinatal networks, covering 231 eligible maternity units, agreed to support this 6-month project (1 February 2011 to 31 July 2011). Finally, 182 maternity units participated, for a participation rate of $78.79 \%$ maternity units (84 level I, 69 level II and 29 level III). In 10 perinatal networks (50\% of those participating), all of the network's maternity units participated. Table 1 compares the characteristics of the French maternity units that participated and those that did not.
Table 1 Comparison of the characteristics of French maternity units that did and did not participate in the study

\begin{tabular}{|c|c|c|c|}
\hline & $\begin{array}{l}\text { Participants } \\
n=181 \\
\%\end{array}$ & $\begin{array}{l}\text { Non-participants }{ }^{a} \\
n=377 \\
\%\end{array}$ & $p$ value \\
\hline \multicolumn{4}{|l|}{ Total no. deliveries ${ }^{b}$} \\
\hline$<250$ & 7.7 & 11.4 & 0.12 \\
\hline $250-749$ & 58.0 & 49.9 & \\
\hline$\geq 750$ & 34.3 & 38.7 & \\
\hline \multicolumn{4}{|l|}{ Level of care ${ }^{c}$} \\
\hline Level I & 45.9 & 50.1 & 0.22 \\
\hline Level II & 38.1 & 38.2 & \\
\hline Level III & 16.0 & 11.7 & \\
\hline \multicolumn{4}{|l|}{ Type of facility } \\
\hline University hospital & 8.8 & 8.8 & 0.02 \\
\hline General hospital & 64.1 & 52.5 & \\
\hline Private hospital & 27.1 & 38.7 & \\
\hline \multicolumn{4}{|l|}{ Region $^{d}$} \\
\hline Province & 82.9 & 82.8 & 0.97 \\
\hline Île de France & 17.1 & 17.2 & \\
\hline
\end{tabular}

${ }^{a}$ Maternity units that did not participate in the study among all French maternity units, according to 2010 healthcare facility statistics ${ }^{b}$ Delivery during the 6-month study period

'Level I: no neonatology department. Level II: presence of a department of neonatology and special care in the same building or immediate proximity to the site of delivery. Level III: neonatal intensive care present in the same building (in addition to neonatology units) or immediate proximity to the delivery room

${ }^{d}$ lle de France includes Paris and its metropolitan area. Province is all other French regions

In each case of postpartum hemorrhage (defined as blood loss $>500 \mathrm{~mL}$ for vaginal delivery and $>1000 \mathrm{~mL}$ for cesareans in the $24 \mathrm{~h}$ after delivery), the medical and/or surgical treatment and maternal outcomes were recorded. Blood loss was to be estimated visually with the habitual method used in each unit and specified in each woman's records. Professionals in each unit collected data prospectively for 6 months, entering it onto electronic case report forms via a secure website.

The principal endpoint was the incidence of PPH.

Quality control was performed in $30 \%$ of the maternity units in each participating network, selected by random drawing, from September 2011 to November 2012. In each of the selected maternity wards, $10 \%$ of the study files (again, randomly selected) were verified manually as were the birth registers, either by a supervisor of the perinatal network or by one of the two midwives coordinating the study nationwide. One maternity ward was excluded from the statistical analysis because it refused to participate in the quality control procedure. Finally 53 maternity units were audited (and 108 records verified). 


\section{Statistical analysis}

The $X^{2}$ test (or Fisher's exact test when appropriate) was used to compare the qualitative variables and Student's $t$ test for the quantitative variables. Clinically relevant crude relative risks (RR) were calculated (cesareans compared with vaginal deliveries), with their $95 \%$ confidence intervals $(95 \% \mathrm{CI})$. The analysis was performed with STATA software (version 13, Statacorp, College Station, TX, US). A $P$ value $<.05$ was considered significant.

\section{Results}

Table 2 describes the women's medical characteristics. Women in the cesarean group were older, gave birth at an earlier gestational age, and had more multiple pregnancies $(P<.001)$.

During the study period there were 129,110 deliveries in the participating maternity units (103,733 vaginal and 25,377 cesarean) with $4207 \mathrm{PPH}$ reported, including 3488 after vaginal delivery, 714 PPH after cesareans, and 5 after a cesarean performed on the second twin.

The incidence of PPH $(>500 \mathrm{~mL})$ after vaginal delivery was $3.36 \%$ [95 \% CI: 3.25-3.47 \%] and after cesareans (>1000 mL) $2.83 \%$ [9 5\% CI: $2.63-3.04 \%]$. The incidence of severe PPH after vaginal delivery $(\geq 1000 \mathrm{~mL})$ was $1.11 \%$ [95 \% CI: 1.05-1.18] and after cesareans $(\geq 1500 \mathrm{~mL}) 1.0 \%$ [95 \% CI: 0.88-1.13\%].

For vaginal deliveries, the incidence of transfusions among the women with mild $\mathrm{PPH}(>500 \mathrm{~mL}$ and $<$ $1000 \mathrm{~mL}$ ) was $4.95 \%$ [95 \% CI: 4.08-5.93], and among those with severe PPH 28.45 \% [95 \% CI: 25.87-31.13]. For the cesareans, the incidence of transfusions with mild PPH $(>1000 \mathrm{~mL}$ and $<1500 \mathrm{~mL}$ ) was $33.16 \%$ [95 \% CI: 28.54-38.05] and among those with severe PPH 64.54\% [95 \% CI: 58.28-70.46].

The incidence of PPH varied according to maternity unit characteristics (number of deliveries, type of hospital, and region) for cesareans $(P<.003)$ and for vaginal deliveries $(P<.001)$ (except for the number of deliveries) (Table 3).

The principal cause of PPH for both modes of delivery was uterine atony $(57.7 \%$ for vaginal births and $66.3 \%$ for cesareans) (Table 4). The second and third leading causes of PPH after vaginal delivery were, respectively, placental retention $(38.7 \%)$ and perineal tears and lacerations $(24.9 \%)$. For cesareans, the second leading cause was surgical complications (16.4\%) and the third abnormalities of placental insertion (12.7\%). Finally, in $8.5 \%$ of the $\mathrm{PPH}$ after cesareans, the cause was not determined

Table 2 Description of medical data of women who had a PPH

\begin{tabular}{|c|c|c|c|}
\hline Women with PPH & $\begin{array}{l}\text { Vaginal delivery and PPH } \\
n=3488 \\
\%[\text { mean } \pm \text { SD }]\end{array}$ & $\begin{array}{l}\text { Cesarean and PPH } \\
n=719 \\
\%[\text { mean } \pm \text { SD }]\end{array}$ & $p$ value \\
\hline Delivery at term (weeks) & {$[39.7 \pm 2.2]$} & {$[38.3 \pm 3.1]$} & $<.0001$ \\
\hline Singletons & 96.8 & 87.7 & $<.0001$ \\
\hline \multicolumn{4}{|l|}{ Women's age } \\
\hline$<18$ years & 0.8 & 0.1 & \multirow[t]{3}{*}{$<.0001$} \\
\hline 18-35 years & 83.5 & 70.7 & \\
\hline$\geq 35$ years & 15.7 & 29.2 & \\
\hline Hemoglobin before delivery $(\mathrm{mL})$ & $\begin{array}{l}n=3335 \\
{[11.9 \pm 1.1]}\end{array}$ & $\begin{array}{l}n=699 \\
{[11.7 \pm 1.2]}\end{array}$ & $<.0001$ \\
\hline Lowest postpartum hemoglobin (mL) & $\begin{array}{l}n=3169 \\
{[9.0 \pm 1.6]}\end{array}$ & $\begin{array}{l}n=690 \\
{[8.2 \pm 1.6]}\end{array}$ & $<.0001$ \\
\hline Total estimated blood loss (mL) & $\begin{array}{l}n=3398 \\
{[895 \pm 460]}\end{array}$ & $\begin{array}{l}N=663 \\
{[1513 \pm 816]}\end{array}$ & - \\
\hline \multicolumn{4}{|l|}{ Estimated blood loss ${ }^{a}$} \\
\hline Bag and/or aspiration and/or drains & $\begin{array}{l}n=3465 \\
90.4\end{array}$ & $\begin{array}{l}n=711 \\
79.4\end{array}$ & $<.0001$ \\
\hline Weighed & $\begin{array}{l}n=3466 \\
15.4\end{array}$ & $\begin{array}{l}n=710 \\
20.7\end{array}$ & .0005 \\
\hline Subjective measurement & $\begin{array}{l}n=3464 \\
21.5\end{array}$ & $\begin{array}{l}n=710 \\
38.9\end{array}$ & $<.0001$ \\
\hline Active management of third stage of labor ${ }^{b}$ & $\begin{array}{l}n=3469 \\
79.8\end{array}$ & $\begin{array}{l}n=703 \\
90.7\end{array}$ & $<.0001$ \\
\hline
\end{tabular}

${ }^{a}$ To participate in the study, blood loss had to be estimated visually but additional modes of estimation used in the maternity units were also considered. The estimate of blood loss could requires various combined methods of measurement, such as aspiration and the weighing of compresses during a cesarean ${ }^{b}$ Active management of the third stage of labor was defined as the use of uterotonic agents after childbirth. It was performed in $73.7 \%$ of the cesareans with PPH immediately after birth and in $25.6 \%$ of cases after delivery of the placenta. In vaginal deliveries, active management of the third stage of labor began at the emergence of the anterior shoulder in $91.5 \%$ of cases, immediately after birth in 7.3 , and in $0.9 \%$ of cases after placental delivery 
Table 3 Incidence of PPH according to maternity unit characteristics

\begin{tabular}{|c|c|c|c|c|}
\hline & \multicolumn{2}{|l|}{ Vaginal deliveries } & \multicolumn{2}{|l|}{ Cesareans } \\
\hline & $\begin{array}{l}n=103,733 \\
\%[95 \% \mathrm{Cl}]\end{array}$ & $p$ value & $\begin{array}{l}n=25,377 \\
\%[95 \% \mathrm{Cl}]\end{array}$ & $p$ value \\
\hline \multicolumn{5}{|l|}{ No. deliveries ${ }^{a}$} \\
\hline$<250$ & $3.84[3.07-4.73]$ & .11 & 1.31 [0.53-2.69] & $<.001$ \\
\hline $250-749$ & $3.23[3.06-3.41]$ & & $2.20[1.92-2.51]$ & \\
\hline$>750$ & $3.43[3.29-3.58]$ & & $3.29[3.01-3.59]$ & \\
\hline \multicolumn{5}{|l|}{ Level $^{b}$} \\
\hline । & 2.77 [2.58-2.96] & $<.001$ & $1.94[1.63-2.29]$ & $<.001$ \\
\hline$\|$ & $3.26[3.09-3.44]$ & & $2.50[2.21-2.83]$ & \\
\hline III & $4.05[3.83-4.27]$ & & $4.05[3.63-4.51]$ & \\
\hline \multicolumn{5}{|l|}{ Region ${ }^{c}$} \\
\hline Ile de France & $2.78[2.57-3.01]$ & $<.001$ & $2.27[1.91-2.68]$ & .003 \\
\hline Province & 3.52 [3.39-3.65] & & $3.01[2.77-3.26]$ & \\
\hline
\end{tabular}

${ }^{\mathrm{a}}$ Number of deliveries during the 6-month study period

bLevel I: no neonatology department. Level II: presence of a department of neonatology and special care in the same building or immediate proximity to the site of delivery. Level III: neonatal intensive care present in the same building (in addition to neonatology units) or immediate proximity to the delivery room

Ille de France includes Paris and its metropolitan area. Province: all other French regions (vs. $1.6 \%$ in vaginal deliveries). The risk of uterine atony was 1.15 times more frequent [95\%CI: 1.08-1.22] and the risk of intraoperative complications 190 times more frequent [95 \% CI: 60.84-598.46] for cesarean compared with vaginal deliveries (Table 4). When we limited the comparison of $\mathrm{PPH}$ for the 2 types of delivery by defining them by the same volume of blood loss $(>1000 \mathrm{~mL})$, the results pointed in the same direction (except for uterine atony, which no longer differed according to mode of delivery)[data not shown] (see Additional file 1: Table S1).

The estimate of blood loss was more often subjective for cesarean than vaginal deliveries $(38.9$ vs. $21.5 \%)(P<.0001)$; similarly use of active management of the third stage of labor (injection of uterotonic agents) was more frequent for cesareans (90.7 vs. $79.8 \%)(P<.0001)$ (Table 2). Oxytocin was the uterotonic used after cesareans in $86.7 \%$ of the cases, with carbetocin used in $13.3 \%$. Oxytocin was used in $98.4 \%$ of the PPH after vaginal deliveries.

Women with $\mathrm{PPH}$ after vaginal delivery received the following pharmacological products: oxytocin in $89.8 \%$ of cases $(n=3473)$, prostaglandins in $33.0 \%(n=3472)$, fibrinogen in $2.8 \%(n=3473)$, factor VIIa in $0.5 \%$ $(n=3472)$, and tranexamic acid in $5.1 \%(n=3473)$. After cesareans, they received oxytocin in $76.6 \%(n=709)$, prostaglandins in $57.1 \%(n=711)$, fibrinogen in $10.8 \%$ $(n=711)$, factor VIIa in $1.1 \%(n=711)$, and tranexamic acid in $14.3 \%(n=711)$.

Table 4 Causes of PPH according to mode of delivery

\begin{tabular}{|c|c|c|c|c|}
\hline Causes of $\mathrm{PPH}^{\mathrm{a}}$ & $\begin{array}{l}\text { Vaginal delivery and PPH } \\
n=3488 \\
\%^{\mathrm{a}}\end{array}$ & $\begin{array}{l}\text { Cesarean and PPH } \\
n=719 \\
\%^{\mathrm{a}}\end{array}$ & Crude RR ${ }^{\mathrm{b}}[95 \% \mathrm{Cl}]$ & $p$ value \\
\hline Uterine atony & 57.7 & 66.3 & $1.15[1.08-1.22]$ & $<.0001$ \\
\hline Placental retention & 38.7 & 2.6 & $0.07[0.04-0.11]$ & $<.0001$ \\
\hline Vaginal and/or perineal lacerations & 24.9 & 1.7 & - & - \\
\hline Episiotomy & 19.4 & 0.8 & - & - \\
\hline Anomaly of placental insertion & 1.9 & 12.7 & - & - \\
\hline Uterine rupture $^{c}$ & 0.4 & 1.7 & 4.15 [1.93-8.95] & - \\
\hline Cervical lacerations & 3.4 & 0.8 & - & - \\
\hline Vaginal thrombus & 1.3 & $0.4^{c}$ & - & - \\
\hline \multicolumn{5}{|l|}{ Others } \\
\hline intraoperative complications & 0.1 & 16.4 & 190.81 [60.84-598.46] & $<.0001$ \\
\hline hemorrhagic normal 3rd stage ${ }^{d}$ & 0.3 & 0.1 & - & - \\
\hline amniotic fluid embolism & 0.1 & 0.1 & - & - \\
\hline uterine inversion & 0.1 & 0.0 & - & - \\
\hline coagulation disorders & 0.2 & 2.6 & - & - \\
\hline not determined ${ }^{e}$ & 1.6 & 8.5 & - & - \\
\hline
\end{tabular}

${ }^{a}$ One woman could have had several causes that explain her PPH

${ }^{\mathrm{b}}$ cesareans vs. vaginal deliveries

'There were 3 trials of vaginal delivery ( 1 woman with an episiotomy and placental retention, 1 woman with no other anomaly, and 1 woman with a uterine rupture and a vaginal laceration)

${ }^{\mathrm{d}}$ Hemorrhagic normal third stage: excessive blood loss during a normal separation of the placenta from the uterine wall

${ }^{\mathrm{e}}$ The professionals were unable to select a principal cause for the $\mathrm{PPH}$ 
The non-pharmacological procedures, that is, secondline treatments, are described in Table 5. Manual uterine examination was reported in $80 \%$ of the $\mathrm{PPH}$ after vaginal deliveries. Intrauterine balloon treatment was still infrequent during the study period. Vessel embolization by interventional imaging was 3.4 times [95 \% CI: 2.58-4.63] more frequent among women with cesareans than those with vaginal deliveries (10.0 vs. $2.9 \%$ ). At the same time, surgical procedures were less frequent after cesarean than vaginal deliveries ( 25.5 vs. $42.6 \%$ ) $[R R=0.6 ; 95 \% \mathrm{CI}: 0.52-0.68]$. After excluding surgical procedures of the perineum, the RR for surgical procedures was 5.36 [95 \% CI:4.22-6.82] after cesarean compared with vaginal deliveries (23.5 vs. $4.4 \%)$. Women with cesareans required transfusions more often (44.4 vs. $12.7 \%$ ) [RR $=3.5$; $95 \%$ CI: 3.11-3.95] (Table 5).

Again, if we limit the comparison of the two types of delivery by defining PPH by the same volume of blood loss $(>1000 \mathrm{~mL})$, the results again pointed in the same direction, with arterial embolization still more frequent but no longer statistically significantly $(10.0 \%$ vs. $8.1 \%$; $\mathrm{RR}=1.24$ [95 \% CI: 0.89-1.71] and transfusion of packed red blood cells $[\mathrm{RR}=1.27$; $95 \% \mathrm{CI}: 1.12-1.44]$ more frequent for cesarean deliveries [data not shown] (see Additional file 2: Table S2).

\section{Discussion}

\section{Study strengths and limitations}

This study covered 129,110 of the 786,559 deliveries recorded in France in 2011 and accounted for $32.82 \%$ of all deliveries during the 6 months of the study [32]. However, private hospitals participated at a lower rate than the other types of hospitals (Table 1). Among the 20 perinatal networks that agreed to support the study, the participation rate was satisfactory $(78.79 \%)$. This participation was total (100 \% of their maternity units) for $50 \%$ of the networks. The definition of PPH was standardized and the data collection prospective, in a daily clinical setting. Substantial quality control to verify data input quality was performed in $30 \%$ of the maternity units.

The choice to use different definitions of PPH according to mode of delivery can be debated. Based on a discussion between obstetricians, it was intended to facilitate the participation of the obstetrics professionals in the maternity units. A large number of obstetricians considered that a threshold of $500 \mathrm{~mL}$ for cesareans was inappropriate, both because it would considerably increase the number of PPH among cesareans and because the amniotic fluid aspired at the moment of incision makes this threshold unreliable. Moreover, although the

Table 5 Non-pharmaceutical curative second-line procedures performed for PPH

\begin{tabular}{|c|c|c|c|c|}
\hline Non-pharmaceutical procedures & $\begin{array}{l}\text { Vaginal delivery and PPH } \\
n=3488 \\
\%\end{array}$ & $\begin{array}{l}\text { Cesarean and PPH } \\
n=719 \\
\%\end{array}$ & Crude $\operatorname{RR}^{f}[95 \% \mathrm{Cl}]$ & $p$ value \\
\hline Manual uterine examination & 80.0 & - & - & - \\
\hline Intrauterine balloon & 0.9 & 1.0 & $1.06[0.47-2.39]$ & .9 \\
\hline Radiologic artery embolization & 2.9 & 10.0 & $3.46[2.58-4.63]$ & $<.0001$ \\
\hline Surgical procedures ${ }^{a}$ & 42.6 & 25.5 & $0.60[0.52-0.68]$ & $<.0001$ \\
\hline B-Lynch suture & 0.3 & 3.9 & - & - \\
\hline Ho Cho suture & 0.1 & 3.5 & - & - \\
\hline Hypogastric arterial ligation & 0.3 & 6.5 & - & - \\
\hline Other vessel ligation & 0.5 & 10.3 & - & - \\
\hline Cervical suture & $3.0^{b}$ & 0.7 & - & - \\
\hline Suture of a vaginal laceration & 39.9 & 2.5 & - & - \\
\hline Hysterectomy & 0.4 & 5.6 & - & - \\
\hline Repair of uterine wound closure & - & 2.8 & - & - \\
\hline Evacuation of hematoma of the abdominal wall & 0 & 0.7 & - & - \\
\hline Other surgery & $0.3^{c}$ & $6.1^{d}$ & - & - \\
\hline Transfusion of packed red blood cells & 12.7 & 44.4 & $3.5[3.11-3.95]$ & $<.0001$ \\
\hline Maternal death & $0.03^{e}$ & 0 & - & - \\
\hline
\end{tabular}

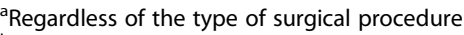

${ }^{\mathrm{b}}$ Among women with a cervical laceration, we note 3 emergency hysterectomies

cCorresponds to 8 uterine ruptures sutured without a hysterectomy and one traction rotation of the cervix with forceps

${ }^{\mathrm{d} C}$ Corresponds to 3 uterine ruptures sutured without a hysterectomy and 6 sutured bladder lacerations; 2 laparotomies with ablation of clots without active

bleeding ; 1 laparatomy for a retroperitoneal hematoma, and a ruptured hepatic adenoma ; 2 laparotomies with reoperation of the uterus and evacuation of intrauterine clots

eOne maternal death

${ }^{\mathrm{f}}$ Cesareans vs. vaginal deliveries 
French guidelines of December 2014 clearly define PPH as blood loss $\geq 500 \mathrm{~mL}$, regardless of mode of delivery, the definition was less clear in the 2004 guidelines, in effect during the study period [33, 34]. We further note that the American College of Obstetricians and Gynecologists uses the same definition we did: > $500 \mathrm{~mL}$ for vaginal deliveries and $>1000 \mathrm{~mL}$ for cesareans [35].

Another criticism is that the determination of the volume of blood loss was not more objective. Visual estimates of blood loss are known to be inaccurate and associated with an underestimation of blood loss $[11,36]$. However, it is the first-line method available to physicians in the immediacy of decision making and it is widely used in French maternity wards. In a large European trial, the use of a collection bag compared with visual estimates of blood loss after vaginal delivery was not found to reduce the rate of severe PPH [37].

\section{Interpretation}

The incidence of PPH $(>500 \mathrm{~mL})$ after vaginal delivery was $3.36 \%$ [95 \% CI: 3.25-3.47\%], slightly lower than the percentage reported in several studies $[14,19,23]$. However, the studies that measured blood loss objectively, as opposed to subjectively, have showed higher prevalence rates [23]. Elsewhere, there is a wide variation in PPH rates throughout the world [23]. The incidence of severe $\mathrm{PPH}(\geq 1000 \mathrm{~mL})$ after vaginal delivery was $1.11 \%$ [95 \% CI: 1.05-1.18], lower than reported by some authors $[17,38]$ and similar to the results in another French study [20]. Here again, this prevalence varies widely internationally $[23,30]$. The incidence of $\mathrm{PPH}(>1000 \mathrm{~mL})$ after cesareans was $2.83 \%$ [95 \% CI: 2.63-3.04\%], similar to other reported rates [37, 39], and the incidence of severe PPH $(\geq 1500 \mathrm{~mL})$ after cesareans was $1.0 \%$ [95 \% CI: $0.88-1.13 \%$ ]. It is not always easy to compare the published studies because the definition of severe PPH varies from study to study and is not often defined simply as a volume of blood loss $[20,21,25]$. Finally, despite definitions of PPH that vary by mode of delivery, authors generally calculate an overall incidence of $\mathrm{PPH}$ without distinguishing the mode of delivery [12, 18, 29, 40-42]. The incidence of $\mathrm{PPH}$ here varied according to maternity unit level, contrary to the results in another French study [20]. The incidence of PPH varied in our study according to number of deliveries only for the cesareans; this is unsurprising because patients at risk of PPH are most often referred to Level III units, which are also the largest. Nonetheless, a US study found a higher rate of $\mathrm{PPH}$ in the lowest volume rural hospitals than in nonrural hospitals, for both cesareans and spontaneous vaginal deliveries [43].

Blood loss volume was measured subjectively in $21.5 \%$ of the PPH after vaginal delivery, compared with $38.9 \%$ of those after cesareans. This may explain in part the more frequent use in France of second-line treatments, which underlines a possible delay in diagnosis [14]. It should be noted that in France, most maternity units do not routinely perform blood counts, except in PPH identified by the volume of blood loss or by clinical signs of hypovolemia or anemia. Finally, active management of the third stage of labor was performed for only $79.8 \%$ of the $\mathrm{PPH}$ after vaginal delivery and $90.7 \%$ after cesareans, although the 2004 French guidelines recommended this management routinely for all deliveries [33]: active management of the third stage of labor, including the prophylactic application of uterotonics, is considered a key point in the prevention of $\mathrm{PPH}$ [44]. Oxytocin is the agent used most frequently, even after cesareans. The percentage of active management of the third stage of labor has increased in France since 2006 [45]. It is probable that the national rate in 2015 is still better, after the 2014 publication of the updated French guidelines. Our results are consistent with those from a database collecting information regularly from volunteer French maternity units [46].

Unsurprisingly, uterine atony was the most common cause of PPH both for vaginal and cesarean deliveries (Table 4), but our results highlight the frequency of multiple causes in the same patient. The third leading cause of $\mathrm{PPH}$ after vaginal delivery was perineal tears or lacerations, and the fourth leading cause episiotomies. Episiotomies remain relatively common in France, with an overall rate around $28.5 \%$ [46] and a rate in nulliparas around $45 \%$ [46, 47]. The second leading cause of PPH during cesareans in our study was related to the surgical incision (16.4\%). To our knowledge, this is the first study to detail the causes of $\mathrm{PPH}$ associated with surgical procedures among the cesareans with PPH. The extension of the uterine incision at cesarean delivery is well known to obstetricians $[21,48,49]$, but other causes of PPH after a cesarean can include uterine bleeding due to incision into the muscle, active bleeding persisting after suture of the incision, and hematomas, either subperitoneal or of the broad ligament or the uterine wall, or due to an incision either transplacental or through a highly vascularized lower segment. The rate of relaparotomy after cesarean delivery is thought to be around 1.5-2 \% [49-51]. Levin et al. found that $89.3 \%$ of the indications for relaparotomy after cesareans were associated with hemorrhagic complications (28 relaparotomies for 17,482 cesareans) [50]. The surgical incision during cesareans is therefore associated with immediate or secondary hemorrhagic complications, to which we must add non-hemorrhagic intraoperative or postoperative complications $[48,52,53]$. These risks of immediate (not to mention longer-term) complications must encourage obstetricians to limit the number of cesareans and therefore to avoid choosing to perform first cesareans, especially among nulliparous women. 
The pharmacologic treatments used in this study show notable use of tranexamic acid, fibrinogen, and recombinant activated factor VII; they were used more often after cesareans and signal that these deliveries entailed more serious $\mathrm{PPH}$.

Among the non-pharmacological curative second-line procedures, we see that the intrauterine balloon tamponade was still little used in France at that time, unlike in UK maternity units [54]. Use of balloon tamponade is relatively recent in France, and the first small French series was not published until 2012 [55]. This technique has since been spreading among French maternity units and is now proposed after failure of prostaglandin treatment by the 2014 French guidelines [34]. We also note that embolization is fairly frequent in France, particularly after cesareans, somewhat surprisingly. That is, one would expect more revision surgery after cesareans, but that may be explained by the delayed character of $\mathrm{PPH}$ in the recovery room or during postpartum monitoring, and by easy access to vascular embolization platforms in larger maternity units, outside the Paris region. Emergency hysterectomy was, as in the literature, more frequent after cesareans $(5.6 \%)[28,56-59]$. Second-line treatment of PPH remains challenging, since we lack sufficient scientific evidence from randomized controlled trials for choosing the specific treatment.

After vaginal deliveries, $12.7 \%$ of the women with PPH had transfusions (vs. $44.4 \%$ for the cesareans with $\mathrm{PPH})$. The transfusion rate after vaginal deliveries reported here is higher than that observed in other studies $[14,60]$. The excess risk of transfusion after cesareans also varies according to parity, number of previous cesareans, and type of cesarean (elective vs. emergency), but these factors were not collected in this study [61-63].

\section{Conclusion}

The incidence of PPH after vaginal delivery was $3.36 \%$ and after a cesarean $2.83 \%$. The incidence of severe PPH after vaginal delivery was $1.11 \%$ and after a cesarean $1.00 \%$. This incidence rate varied according to maternity unit characteristics. The principal cause of $\mathrm{PPH}$ for both modes of delivery was uterine atony, which is therefore the obstetric complication for which improvement in prevention, identification, and management remain important priorities in maternity units.

It is essential to have harmonized international definitions of PPH after vaginal and cesarean deliveries, whether it is volume or method of collection of blood loss, in order to facilitate the comparison of the incidence and prevalence rates of PPH in both developed and low-income countries. Moreover, studies should seek to assess the methods to optimize immediate diagnosis of $\mathrm{PPH}$, such as improvements in the visual estimates of blood loss (simulations of clinical scenarios, posters with photographs of blood losses accompanied by a calibrator to help determine the blood volume) or weighing the lost blood.

\section{Additional files}

Additional file 1: Table S1. Description of data: Causes of PPH $>1000 \mathrm{~mL}$ according to mode of delivery. (DOCX $18 \mathrm{~kb}$ )

Additional file 2: Table S2. Description of data: Non-pharmaceutical curative second-line procedures performed for PPH> $1000 \mathrm{~mL}$. (DOCX 19 kb)

\section{Abbreviations}

CECIC, Comité d'Ethique des Centres d'Investigation Clinique; HERA Group, [postpartum HEmoRrhAge] group; IRB, Institutional review board; PPH, Postpartum hemorrhage

\section{Acknowledgements}

'HERA GROUP: Bernard Branger, MD, is a pediatrician; Laure Connan, MD, is an obstetrician-gynecologist; Catherine Crenn-Hébert, MD, is an obstetriciangynecologist; Caroline Da Costa Correia is a midwife; Michel Dreyfus, MD, $\mathrm{PhD}$, is a professor in obstetrics and gynecology; Paul Lefèvre, MD, is an obstetrician-gynecologist; Anne Legrand, MD, is a statistician.

\section{Funding}

This study was supported by a grant from the French Ministry of Health (PHRCN 2009, N 05-05).

\section{Availability of date and material}

The datasets generated and analyzed during the current study are not publicly available because they belong to the institutional promotor of the Hera study (Centre Hospitalier Universitaire de Clermont-Ferrand), but are available from the corresponding author on reasonable request.

\section{Authors' contributions}

FV, BB and DL designed the study. FV, BP, CB carried out the analysis. FV wrote the first draft of the manuscript. FV and DL obtained the funding for the study. FV, CB, BP, AL and DL supervised the interpretation of the analysis. The Hera group, including all the authors, helped in revising the manuscript and monitoring the national study. All authors read and approved the final manuscript.

\section{Authors' information}

$\mathrm{FV}, \mathrm{MD}, \mathrm{PhD}$, is an obstetrician-gynecologist and an epidemiologist. $C B, M S$, is a research midwife.

$\mathrm{BP}, \mathrm{PhD}$, is a statistician.

$\mathrm{DL}, \mathrm{MD}, \mathrm{PhD}$, is a professor in obstetrics and gynecology.

\section{Competing interest}

None of the authors has any conflict of interest concerning the topic or contents of this article.

\section{Consent for publication \\ 'Not applicable'}

Ethics approval and consent to participate

This study was approved by a French institutional review board (Comité d'Ethique des Centres d'Investigation Clinique de I'Inter-région Rhônes-Alpes-Auvergne, Grenoble: CECIC): IRB 0917 on 9 November 2009]. According to the French law for the observational studies, all participants provided oral informed consent.

\section{Author details}

'Pôle Femme et Enfant, Centre Hospitalier Universitaire de Clermont-Ferrand, Clermont-Ferrand 63003, France. '2Université d'Auvergne, EA 4681, PEPRADE (Périnatalité, grossesse, Environnement, PRAtiques médicales et DEveloppement), Clermont Université, Clermont-Ferrand, France. ${ }^{3}$ AUDIPOG 
(Association des Utilisateurs de Dossiers Informatisés en Pédiatrie, Obstétrique et Gynécologie), Faculté de médecine RTH Laennec, Lyon, France. ${ }^{4}$ Direction de la Recherche clinique, Centre Hospitalier Universitaire de Clermont-Ferrand, Clermont-Ferrand 63003, France.

\section{Received: 29 July 2015 Accepted: 4 August 2016}

Published online: 24 August 2016

\section{References}

1. Khan KS, Wojdyla D, Say L, Gulmezoglu AM, Van Look PF. WHO analysis of causes of maternal death: a systematic review. Lancet. 2006;376:1066-74.

2. Rossi CA, Mullin P. The etiology of maternal mortality in developed countries: a systematic review of the literature. Arch Gynecol Obstet. 2012; 285:1499-503.

3. Saucedo M, Deneux-Tharaux C, Bouvier-Colle MH, French national experts committee on maternal mortality. Ten years of confidential inquiries into maternal death in France, 1998-2007. Obstet Gynecol. 2013;122:752-60. doi: 10.1097/AOG.0b013e31829fc38c.

4. Zhang WH, Alexander S, Bouvier-Colle MH, Macfarlane A, The MOMS-B Group. Incidence of severe pre-eclampsia, postpartum haemorrhage and sepsis as a surrogate marker for severe maternal morbidity in a European population-based study: the MOMS-B survey. BJOG. 2005;112:89-96.

5. Koeberlé $P$, Lévy A, Surcin S, Bartholin F, Clément G, Bachour K, Boillot A, Capellier G, Riethmuller D. Severe obstetric complications necessitating hospitalization and intensive care: a ten year retrospective study. Ann $\mathrm{Fr}$ Anesth Reanim. 2000:19:445-51.

6. Murphy CM, Murad K, Deane R, Byrne B, Geary MP, McAuliffe FM. Severe maternal morbidity for 2004-2005 in the three Dublin maternity hospitals. Eur J Obstet Gynecol Reprod Biol. 2009;143:34-7.

7. Walterstone M, Bewley S, Wolfe C. Incidence and predictors of severe obstetric morbidity: case-control study. BMJ. 2001;322:1089-94.

8. Euro-Peristat Porject with SCPE and EUROCAT. European Perinatal Health Report. The health and care of women and babies in Europe in 2010. May 2013. [http://www.europeristat.com/images/doc/ EPHR2010_w_disclaimer.pdf]

9. Bouvier-Colle $\overline{M H}$, Varnoux $\mathrm{N}$ et le groupe MOMS-B. Mortalité maternelle et morbidité grave dans trois régions françaises : résultats de MOMS, une enquête européenne multicentrique. J Gynecol Obstet Biol Reprod. 2001;30 (S6):2S5-2S9.

10. Brace V, Penney G, Hall M. Quantifying severe maternal morbidity: a Scottish population study. BJOG. 2004;11:481-4.

11. Rath WH. Postpartum hemorrhage - update on problems of definitions and diagnosis. Acta Obstet Gynecol Scand. 2011;90:421-8.

12. Knight M, Callaghan WM, Berg C, Alexander S, Bouvier-Colle MH, Ford JB, Joseph KS, Lewis G, Liston RM, Roberts CL, Oats J, Walker J. Trends in postpartum hemorrhage in high resource countries: a review and recommendations from the International postpartum hemorrhage collaborative group. BMC Pregnancy Chilbirth. 2009;9:55. doi:10.1186/1471-2393-9-55.

13. Bonnar J. Massive obstetric haemorrhage. Best Pract Res Clin Obstet Gynaecol. 2000;14:1-18.

14. Bonnet MP, Basso O, Bouvier-Colle MH, Dupont C, Rudigoz C, Fuhrer R, Deneux-Tharaux C. Postpartum haemorrhage in Canada and France: a review population-based comparison. PloS one. 2013;8:e66882. doi:10.1371/ journal.pone.0066882.

15. Briley A, Seed PT, Tydeman G, Ballard H, Waterstone M, Sandall J, Poston L, Tribe RM, Bewley S. Reporting errors, incidence and risk factors for postpartum haemorrhage and progession to severe $\mathrm{PPH}$ : a prospective observational study. BJOG. 2014;121:876-88.

16. Mehrabadi A, Hutcheon JA, Lee L, Kramer MS, Liston RM, Joseph KS. Epidemiological investigation of a temporal increase in atonic postpartum haemorrhage: a population-based retrospective cohort study. BJOG. 2013;120:853-62.

17. Oberg AS, Hernandéz-Diaz S, Frisell T, Greene MF, Almqvist C, Bateman BT. Genetic contribution to postpartum haemorrhage in Swedish population: cohort study of 466686 births. BMJ. 2014;349:g4984. doi:10.1136/bmj.g4984

18. Mehrabadi A, Liu S, Bartholomew S, Hutcheon JA, Kramer MS, Liston RM, Joseph KS, for the maternal health study group of the Canadian perinatal surveillance system. Temporal trends in postpartum hemorrhage and severe postpartum hemorrhage in Canada from 2003 to 2010. J Obstet Gynaecol Can. 2014;36:21-33.
19. Ford JB, Roberts CL, Simpson JM, Vaughan J, Cameron CA. Increased postpartum hemorrhage rates in Australia. Int J Gynecol Obstet. 2007;98:237-43.

20. Dupont C, Douzet S, Colin C, Deneux-Tharaux C, Rabillaud M, Clement HJ, Lansac J, Bouvier-Colle MH, Rudigoz RC. Incidence and management of postpartum haemorrhage following the dissemination of guidelines in a network of 16 maternity units in France. Int J Obstet Anesth. 2009:18:320-7.

21. Brace $V$, Kernaghan D, Penney G. Learning from adverse clinical outcomes: major obstetric haemorrhage in Scotland, 2003-05. BJOG. 2007;114:1388-96.

22. Dupont C, Rudigoz RC, Cortet M, Touzet S, Colin C, Rabilloud M, Lansac J, Harvey T, Tessier V, Chauleur C, Pennehouat G, Morin X, Bouvier-Colle MH, Deneux-Tharaux C. Incidence, étiologies et facteurs de risque de I'hémorragie du post-partum : étude en population dans 106 maternités françaises. J Gynecol Obstet Biol Reprod. 2014:43:244-53.

23. Carroli G, Gusta C, Abalos E, Gülmezoglu AM. Epidemiology of postpartum haemorrhage : a systematic review. Best Pract Res Clin Obstet Gynaecol. 2008;22:999-1012

24. Davis D, Baddock S, Pairman S, Hunter M, Benn C, Anderson J, Dixon L, Herbison P. Risk of severe postpartum hemorrhage in low-risk childbearing women in New Zealand: Exploring the effect of place of birth and comparing third stage management labor. Birth. 2012;39:98-105.

25. Kramer MS, Berg C, Abenhaim H, Dahhou M, Rouleau J, Mehrabadi A, Joseph KS. Incidence, risk factors, and temporal trends in severe postpartum hemorrhage. Am J Obstet Gynecol. 2013;209:449.e1-7.

26. Lutomski JE, Byrne BM, Devane D, Greene RA. Increasing trends in atonic postpartum haemorrhage in Ireland: an 11-year population-based cohort study. BJOG. 2012;119:306-14.

27. Roberts $\mathrm{CL}$, Ford JB, Algert CS, Bell JC, Simpson JM, Morris JM. Trends in adverse maternal outcomes during childbirth: a population-based study of severe maternal morbidity. BMC Pregnancy Childbirth. 2009;9:7. doi:10.1186/1471-2393-9-7.

28. Bateman BT, Mhyre JM, Callaghan WM, Kuklina EV. Peripartum hysterectomy in the United States: nationwide 14 year experience. Am J Obstet Gynecol. 2012;206:63.e1-8.

29. Callagan WM, Kuklina EV, Berg CJ. Trends in postpartum hemorrhage: United States, 1994-2006. Am J Obstet Gynecol. 2010;202:353.e1-6.

30. Montufar-Rueda C, Rodriguez L, Jarquin JD, Barboza A, Bustillo MC, Marin F, Ortiz G, Estrada F. Severe postpartum hemorrhage from uterine atony: a multicentric study. J Pregnancy. 2013;2013:525914. doi:10.1155/2013/525914. Epub 2013 Dec 2

31. Audureau E, Deneux-Tharaux C, Lefèvre $P$, Brucato $S$, Morello R, Dreyfus M, Bouvier-Colle MH. Practices for prevention, diagnosis and management of postpartum haemorrhage : impact of a regional multifaced intervention. BJOG. 2009:116:1325-33.

32. Institut National des Etudes démographiques (Ined) [ http://www.ined.fr/fr/ tout-savoir-population/chiffres/france/naissance-fecondite/].

33. Haute autorité de Santé (HAS). Recommandations pour la pratique clinique. Hémorragies du post-partum immédiat. Novembre 2004 [http://www.hassante.fr/portail/upload/docs/application/pdf/HPP_recos.pdf].

34. Collège National des Gynécologues et Obstétriciens Français (CNGOF). Recommandations pour la pratique Clinique. Les hémorragies du post-partum. Décembre 2014 [http://www.cngof.asso.fr/data/RCP/CNGOF 2014 HPP.pdf].

35. American College of Obstetricians and Gynecologists. Clinical management guidelines for obstetrician-gynecologists: postpartum hemorrhage. ACOG Practice Bulletin N76. Obstet Gynecol. 2006;108:1039-47.

36. Glover P. Blood loss at delivery: how accurate is your estimation? Aust J Midwifery. 2003;16:21-4.

37. Zhang WH, Deneux-Tharaux C, Brocklehurst $P$, Juszczak E, Joslin M, Alexander $S$, on behalf of the EUPHRATES Group. Effect of a collector bag for measurement of postpartum blood after vaginal delivery: cluster randomized trial in 13 European countries. BMJ. 2010;340:c293. doi:10.1136/bmj.c293.

38. Rossen J, Ohland I, Nilsen OB, Eggebo TM. Is there an increase of postpartum hemorrhage, and is severe hemorrhage associated with more frequent use of obstetric interventions? Acta Obstet Gynecol Scand. 2010:89:1248-55.

39. Kolas T, Oian P, Skjeldestad FE. Risk for peroperative excessive blood loss in cesarean delivery. Acta Obstet Gynecol. 2010;89:658-63.

40. Cameron CA, Roberts CL, Olive EC, Ford JB, Fischer WE. Trends in postpartum haemorrhage. Aust NZ Public Health. 2005;30:151-6.

41. Kramer MS, Dahhou M, Vallerand D, Liston R, Joseph KS. Risk factors for postpartum hemorrhage: can we explain the recent temporal increase? J Obstet Gynaecol Can. 2011;33:810-9. 
42. Bateman $B T$, Berman MF, Riley LE, Leffert LR. The epidemiology of postpartum hemorrhage in a large, nationwide sample of deliveries. Anesth Analg. 2010;110:1368-73.

43. Snowden JM, Cheng YW, Emeis CL, Caughey AB. The impact of hospital obstetric volume on maternal outcomes in term, non-low-birthweight pregnancies. Am J Obstet Gynecol. 2014;211:1.e1-e7.

44. Westhoff G, Cotter AM, Tolosa JE. Prophylactic oxytocin for the third stage of labour to prevent postpartum haemorrhage. Cochrane Database Syst Rev. 2013;10:CD001808. doi:10.1002/14651858.CD001808.pub2.

45. Vendittelli F, Rivière $\mathrm{O}$, Crenn-Hébert $\mathrm{C}$, Giraud-Roufast A. Do perinatal guidelines have an impact on obstetric practices? Rev Epidemiol Sante Publique. 2012;60:355-62.

46. Association des Utilisateurs de Dossiers Informatisés en Pédiatrie, en Obstétrique et en Gynécologie (AUDIPOG): Database access [http://www. audipog.net/interro-choix.php].

47. Blondel B, Kermarrec M. Enquête nationale périnatale 2010. Les naissances en 2010 et leur évolution depuis 2003. Mai 2011. [http://www.sante.gouv.fr/ IMG/pdf/Les_naissances_en_2010_et_leur_evolution_depuis_2003.pdf]

48. De la Torre L, Gonzàles-Quintero VH, Mayor-Lynn K, Smarkusky L, Hoffman C, Saab A, Diro M. Significance of accidental extension in the lower uterine segment during cesarean delivery. Am J Obstet Gynecol. 2006;194:e4-6.

49. Pallasmaa N, Ekblad U, Aitokallio-Tallberg A, Uotila J, Raudaskoski T, Ulander VM, Hurme S. Cesarean delivery in Finland: maternal complications and obstetric risk factors. Acta Obstet Gynecol Scand. 2010;89:896-902.

50. Levin I, Rapaport AS, Salzer L, Maslovitz S, Lessing JB, Almog B. Risk factors for relaparotomy after cesarean delivery. Int J Gynecol Obstet. 2012;119:163-5.

51. Kessous R, Danor D, Weintraub YA, Witznitzer A, Sergienko R, Ohel I, Sheiner E. Risk factors for relaparotomy after cesarean section. J Matern Fetal Neonatal Med. 2012;25:2167-70.

52. Liu S, Liston RM, Heaman M, Sauve R, Kramer MS, for the maternal health study group of the Canadian Perinatal Surveillance System. Maternal mortality and severe morbidity associated with low-risk planned cesarean delivery versus planned vaginal delivery at term. CMAJ. 2007;176:455-60.

53. Vincent A, Ayzac L, Girard R, Caillat-Vallet E, Chapuis C, Depaix F, Dumas AM, Gignoux C, Haond C, Lafarge-Leboucher J, Launay C, Tissot-Guerraz F, Fabry J. Downward trends in surgical site and urinary tract infection after cesarean delivery in a French surveillance network, 1997-2003. Infect Control Hosp Epidemiol. 2008;29:227-33.

54. Kayem G, Kurinczuk JJ, Alfirevic Z, Spark P, Brocklehurst P, Knight M. Specific second-line therapies for postpartum haemorrhage: a national cohort study. BJOG. 2011;118:856-64.

55. Laas E, Bui C, Popowski T, Mbaku OM, Rozenberg P. Trends in the rate of invasive procedures after the addition of the intrauterine tamponade test to a protocol for management of severe postpartum hemorrhage. Am J Obstet Gynecol. 2012;207:281.e1-7.

56. Spiliopoulos M, Kareti A, Jain NJ, Kruse LK, Hanlon A, Dandolu V. Risk of peripartum hysterectomy by mode of delivery and prior obstetric history: data from a population-based study. Arch Gynecol Obstet. 2011;283:1261-8.

57. Knight M, Kurinczuk JJ, Spark P, Brocklehurst P, for the United Kingdom Obstetric Surveillance System Steering Committee. Cesarean delivery and peripartum hysterectomy. Obstet Gynecol. 2008;1:97-105.

58. Owolabi MS, Blake RE, Mayor MT, Adegbulugbe HA. Incidence and determinants of peripartum hysterectomy in the metropolitan area of the district of Columbia. J Reprod Med. 2013;58:167-72.

59. Bodelon C, Bernabe-Ortiz A, Schiff MA, Reed SD. Factors associated with peripartum hysterectomy. Obstet Gynecol. 2009;114:115-23.

60. Bonnet MP, Deneux-Tharaux C, Dupont C, Rudigoz RC, Bouvier-Colle MH. Transfusion practices in postpartum hemorrhage: a population-based study. Acta Obstet Gynecol Scand. 2013;92:404-13.

61. Goudan A, Kalra JK, Raveendran A, Bagga R, Aggarwal N. Descriptive study of blood transfusion practices in women undergoing cesarean delivery. J Obstet Gynaecol Res. 2011;37:1277-82.

62. Saidu R, Bolaji BO, Olatinwo AWO, Mcintosh CM, Alio AP, Salihu HM. Repeat caesarean delivery as a risk factor for abnormal blood loss, blood transfusion and perinatal mortality. J Obstet Gynaecol. 2011;31:728-31.

63. Rouse DJ, MacPherson C, Landon M, Varner MW, Leveno KJ, Moawad AH, Spong CY, Caritis SN, Meis PJ, Wapner RJ, Sorokin Y, Miodovnik M, Carpentier M, Peaceman AM, O'Sullivan MJ, Sibai BM, Langer O, Thorp JM, Ramin SM, Mercer BM, for the National institute of Child Health and Human Development Maternal-Fetal Medicine units Network. Blood transfusion and cesarean delivery. Obstet Gynecol. 2006;108:891-7.

\section{Submit your next manuscript to BioMed Central and we will help you at every step:}

- We accept pre-submission inquiries

- Our selector tool helps you to find the most relevant journal

- We provide round the clock customer support

- Convenient online submission

- Thorough peer review

- Inclusion in PubMed and all major indexing services

- Maximum visibility for your research

Submit your manuscript at www.biomedcentral.com/submit 